"UK Defence Supply Chain Relationships: a study of Sustained Monopoly" Management Decision, Vol 42 No. 2 (2004) pp259-276

This article is (c) Emerald Group Publishing and permission has been granted for this version to appear here (https://dspace.lib.cranfield.ac.uk/index.jsp). Emerald does not grant permission for this article to be further copied/distributed or hosted elsewhere without the express permission from Emerald Group Publishing Limited. www.emeraldinsight.com

\title{
UK Defence Supply Chain Relationships: a Study of Sustained Monopoly
}

Authors:

Andrew S Humphries

UK Defence Logistics Organisation

Dr Richard Wilding

Cranfield Centre for Logistics and Transportation

School of Management, Cranfield University 
Group Captain Andrew Humphries MBA, PhD, FCMI, MIMIS, RAF is Head of Defence Aviation Supply Chain Policy in the UK Defence Logistics Organisation. With over 30 years of experience as a practicing logistician, he is currently responsible for supply chain and business improvement initiatives for the $£ 900$ m UK military aviation, in-service support. He is earned his PhD as a part-time student at the Cranfield School of Management and can be reached at X106, Defence Logistics Organisation, Wyton, Huntingdon, PE28, 2EA, UK.

Tel: 01480-452451 Ext 5648

E-mail: andrew_humphries@bigfoot.com

Richard Wilding, Ph.D, is a Senior Lecturer at the Centre for Logistics and Supply Chain Management, Cranfield School of Management U.K. Richard works with European and International companies on logistics and supply chain projects in all sectors including pharmaceutical, retail, automotive, high technology, food drink and professional services to name a few. He is a highly acclaimed presenter and regularly speaks at Industrial Conferences and has undertaken lecture tours of Europe and Asia at the invitation of local Universities \& Confederations of Industry. He has published widely in the area of supply chain management and is Editorial Advisor to a number of top journals in the area. He can be reached at Cranfield Centre for Logistics and Supply Chain Management, Cranfield School of Management, Cranfield University, Cranfield, Bedfordshire, UK.

Tel: 01234-751122

E-mail: richard.wilding@cranfield.ac.uk 


\title{
UK Defence Supply Chain Relationships: a Study of Sustained Monopoly
}

\begin{abstract}
Business-to-business, supply chain relationships within sustained monopolies, such as those within UK Defence Procurement, have received scant attention by Management Researchers. This paper describes the results from a substantial, exploratory research project that used Williamson's (1975) Organisations Failure Framework as a theoretical model. Surprisingly, it revealed that many issues surrounding Supply Chain Management implementation were similar to those found in 'normal' markets and that it played an important part in reducing the inherently negative effects of monopolistic relationships. The research sheds new and useful light on the dynamics of this unusual business situation for both managers and academics.
\end{abstract}

Keywords: Supply Chain Management, Monopoly, UK Defence Procurement

\section{Introduction}

Following the ending of the 'Cold War' in 1989, the UK Government has sought a 'peace dividend' through a reduction in expenditure on defence. However, continued participation in international conflicts and peace-keeping operations has required qualitative improvements to military capability to be maintained. With equipment expenditure of $£ 10,408$ million in 2000/01 (DASA, 2002) this is still a strategically important element of UK Government spending and as with other public sector areas, a relentless drive to achieve greater value for money has been pursued. A crucial element of this strategy has been to overcome traditional adversarial attitudes which have resulted in a succession of high-profile cost, time and project performance overruns. The intention has been to establish long-term supply chain partnerships with its industrial suppliers. However, in the face of global spending cutbacks the continued concentration of the Defence Equipment Suppliers has resulted in an increasingly monopolistic situation. This is a very high technology business dealing with politically sensitive, limited availability goods and services in relationships that extend over many years. Each side wields considerable power but, lack of trust and the option to leave reduce efficiency, increase costs and offer little incentive to co-operate (Humphries \& Wilding, 2001, Palmer, 2001, Parker \& Hartley 1997). Moreover, despite clear strategic 
intentions, the practical implementation of partnering arrangements by the UK Ministry of Defence (MoD) have been slow, patchy and clouded by uncertainty over ways and means. Furthermore, the fundamental differences of aims by both sides appear to make the selection of common objectives difficult and problematic. Overcoming these difficulties is the business problem currently faced by UK MoD's Logistics teams and their industrial suppliers as they attempt to create and manage complex supply chains delivering military spare parts, repairs and design services to UK military forces world-wide.

This paper thus explores the role of Supply Chain Management (SCM) in the unusual domain of long-term, monopolistic business-to-business relationships. We first examine views from the literature, describe the difficult task of selecting an appropriate theoretical framework and then describe a substantial research project carried out in the UK Defence Procurement Organisation which employs both quantitative and qualitative methods. It concludes from emergent supply chain relationship factors that the importance of SCM in 'normal' markets is replicated in the monopolistic relationships surveyed although, specific adverse characteristic features are also revealed which may have parallels within the longterm collaborative relationships found in other sectors. We believe this offers practitioners useful guidance and academics with opportunities for further research.

\section{Supply Chain Relationships}

As already mentioned, the business of UK Defence Procurement is essentially the management of supply chain relationships which accords with Tompkins (2000): to achieve by co-operation 'the synchronisation of the physical flow of goods from sourcing to consumption'. In our brief review of the literature we therefore concentrate on the importance of relationships to SCM and compare the private and public sectors. Our aim is to expose the main dynamics in order to seek parallels with the research environment. 
SCM is viewed as an integrative, proactive approach to managing the total flow of a distribution channel to the ultimate customer (Matthyssens \& Van den Bulte, 1994). It aims to increase customer service reliability and reduce inventory (Boddy et al, 2000) to lower uncertainty and costs (Cooper \& Ellram, 1993, Lamming, 1993, Bechtel \& Jayaranth, 1997). It therefore depends upon co-operative relationships throughout the Supply Chain in order to achieve benefits for all participants (Stevens, 1989) and this involves closer relationships between members which include trust, commitment and collaboration (Spekman et al, 1998). The literature contains a great deal of holistic advice on how this should be achieved but, in practice it is generally operationalised as the integration of chains of suppliers to better satisfy customers (Christopher, 1997, Peck et al, 2000). Nevertheless, although suppliers recognise the need to integrate with their customers, it is apparent that full SCM implementation is not being achieved for a number of reasons (Spekman et al, 1998). The importance of long-term partnering relationships to focussing on complex, problem solving (Hulme, 1997) is acknowledged. But, the need to base these arrangements on openness, shared risks and rewards that leverage the skills of each partner to achieve competitive performance not achieved by the individual, is a step that firms find difficult to take (Lambert et al, 1996). Many are still taking a short-term view which tends them towards adversarial relationships (Braithwaite, 1998) and the development of partnering relationships is being obstructed by poor communications allied to reluctance to accept attitudinal change (Anscombe \& Kearney, 1994). Nevertheless, the obligational nature of these arrangements to overcome opportunistic temptations is evident (Ellram \& Edis, 1996) as is the importance of achieving good business-to-business relationships through partnering as a foundation for achieving the operational benefits of SCM (Cooper et al, 1997). We conclude that increased pressures from customers in a more globalised business environment have forced commercial companies to adopt closer relationships with their strategic partners but this demands a substantial 
investment in new management skills and cultural adaptation. UK Defence Procurement supply chain relationships are similarly long termed, inextricably linked and characterised by complex problems and moreover, being also driven by global market conditions (concentration) and increased customer (MoD) sophistication to change (Humphries \& Wilding, 2001).

The review up to this point has predominantly concentrated on concepts developed in the private sector but in comparison, relatively little research has examined SCM within the public sector (Harland et al, 2000). Networking theory considers focal firms but not the larger systems of public sector supply and, describes important context variables but does not consider regulation. Porter's (1980) strategic management framework focuses on individual firm's vertical integration strategies compared to their competitors but does not consider the non-competitive aspects of the private sector. All offer some generalisable features that are relevant but no one model or framework comprehensively addresses public sector SCM relationships (Harland et al, 2000, Zheng, 1998). Harland et al (2000) in their UK Health Authority research list the following distinctive features of public sector supply chain organisations: large and specific services; remote customers; stakeholders are complex, difficult to integrate and crucial to success; dedicated market suppliers; reduced availability of alternatives; accountability to national interest rather than shareholders; the government makes the rules and can sanction anti-competitiveness; investment cycles are long compared to annual reports and returns on investment and finally, the government theme is dominated by politics. These factors are confirmed by Brooks \& Pawar's (2000) research which also concluded that the public sector is different and that the correlation with commercial supply chain relationships cannot be taken as straight forward. However, given that SCM aims to manage a limited number of complex business-to-business relationships over a longer term, 
there are some fundamental similarities of principle that seem to apply (Humphries \& Wilding, 2000).

In conclusion, the importance of improving relationships to achieve successful SCM implementation appears to be well known to academia and business alike and, after more than a decade, is still actively pursued as a strategy by the private and public sectors (Bectel \& Jayaram, 1997, Brooks \& Pawar, 2000, Cooper et al, 1997). The literature has highlighted a number of success and failure factors in the private sector and in more limited coverage of the public sector, identified that similar business motivations exist but are complicated by environmental and stakeholder factors. Although these criteria are useful to this research, a significant gap exists when considering the very long, monopolistic supply chain relationships of the type found within UK Defence Procurement (Humphries \& Wilding, 2001). It is intended that our research would help to fill this void.

\section{A Theoretical Framework for Research}

A lack of research on business relationships within sustained monopolies hampered the search for an appropriate model through which to view UK Defence Procurement relationships. Both Porter's (1980) Five Forces and Cox et al's (2000) Relation Power Analysis considered competition-limiting strategies but appeared to be optimised for use in 'normal' markets. However, Williamson's (1975) Economic Organisations Failure Framework shown in Figure 1 appeared to offer a viable theoretical model for research because it describes a stylised situation in a complex inter-organisational relationship where the costs of managing the risk associated with human factors such as opportunism become too high, the 'market' breaks down and forces a firm to internalise the business, in effect creating an internal monopoly. It is thus possible to hypothesise that within a sustained monopoly of the type found within UK Defence Procurement where neither side has the 
opportunity to escape, the lack of incentive to co-operate might help to perpetuate an adversarial relationship characterised by the features within the boxes of Figure 1 (Humphries \& Wilding, 2000). In this situation the sides do the minimum necessary under the terms of the contract, they take short-term decisions which may cost more in the long-run, because of lack of trust they are reluctant to share proprietary information and may even deliberately distort disclosures such as inflating cost figures in order to justify higher prices, they will opportunistically seek their own objectives rather than and at the expense or joint ones and finally, lack of trust will promote a reliance on the small print of the contract which limits flexibility and adds cost. Examples of these adverse features are certainly portrayed by the press as a tradition of UK Defence Procurement (Humphries \& Wilding, 2000) although it should be noted that Williamson (1975) described the arrows in the framework as

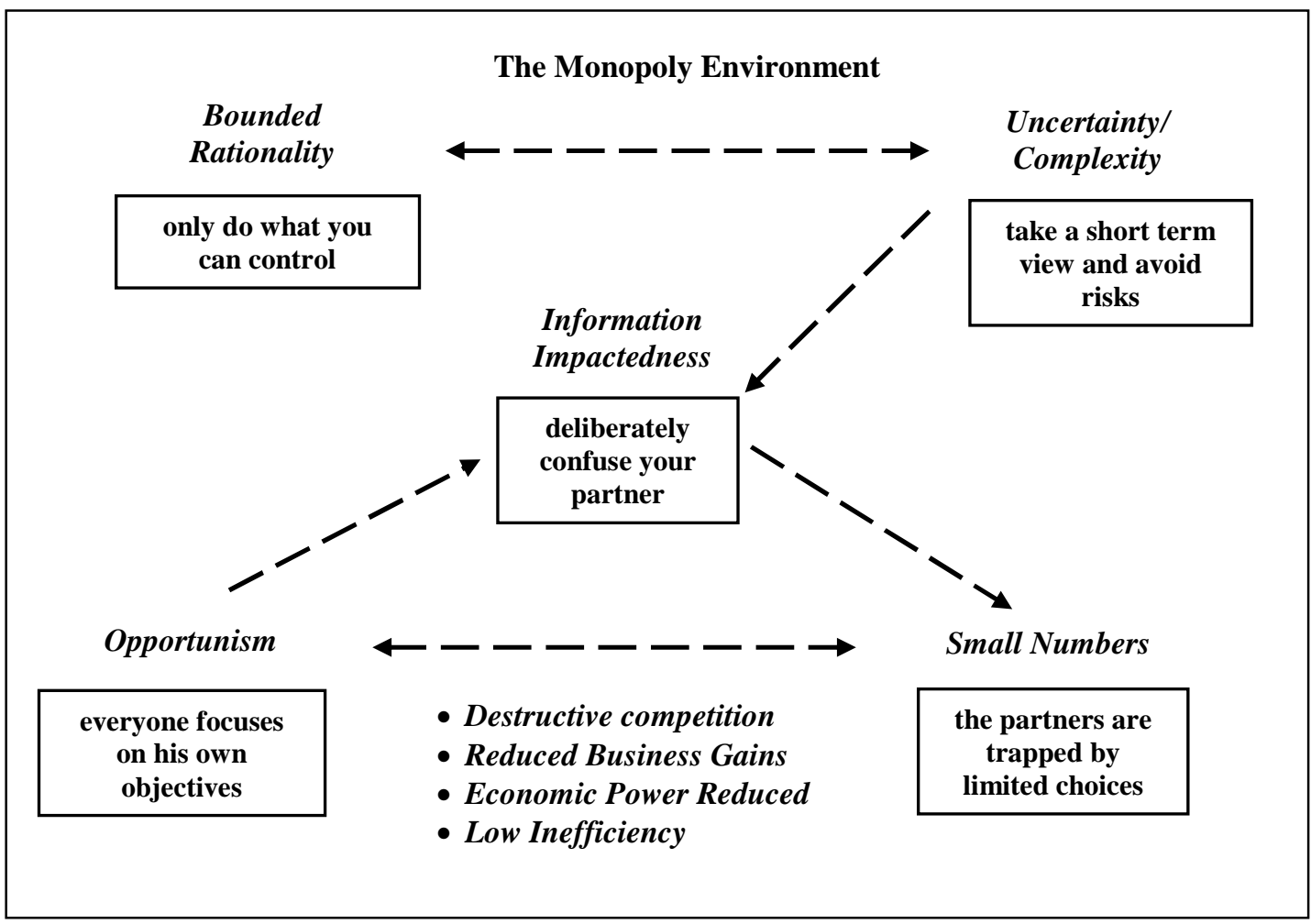

Figure 1. Economic Organisations Failure Framework (adapted from Williamson (1975)

'influences within an environment' rather than a causal interactions. We thus decided to use

Figure 1 as a research model because it appeared to describe a recognisable view of the 
unusual dynamics within UK Defence Procurement relationships. The aim our research was to test this model by seeking empirical evidence of strength and character of each of its 5 dimensions within the relationships examined.

In conclusion, there has been considerable transaction cost economics research which has investigated interorganisational relationships and public utility monopolies but, it has not been well-integrated and no study has utilised Williamson's (1975) Organisations Failure Framework in its entirety (Rindfleisch \& Heide, 1997). This research therefore proposed to exploit this gap whilst examining UK Defence Procurement business relationships.

\section{Methodology - Measuring Relationship Characteristics}

The research aims were thus to understand the relationship dynamics within long-term, collaborative businesses and to determine if relational success factors found within SCM such as trust and collaborative working arrangements were able to assist UK Defence Procurement managers to break out of the essentially negative situation represented by Figure 1. An exploratory research project was designed which used the key informant methods of surveys (600 staff questionnaires - 5 point Likert scales) supported by 115 team-leader semistructured interviews. It took a wide, cross-sectional perspective in order to make a statement about the outcomes of broadly comparable experiences using numerical supporting evidence. The questionnaire questions listed at Appendix 1 were selected from a pool based in the literature and grouped to correspond with the 5 theoretical framework dimensions. On the premise that UK Defence supply chains might contain a spectrum of business relationships, the opposites of the negative definitions of Williamson's (1975) framework were used to label the groups and, questions with a positive orientation were used (validated by focus groups of practitioners during the research pilot phase). 
A self-selected census, (where the MoD managers chose the relationships to be researched), of 54 monopolistic, two-party relationships representing $£ 575.8 \mathrm{~m}$ annual spend within the UK Defence Procurement Organisation (a 10\% sample by value) allowed the collection and analysis of large quantities of data to determine the range and strength of factors within the conceptual framework. It was acknowledged that such a sample could generate skewed results however, follow-up analysis indicated a wide cross-section of the Defence Logistics Organisation businesses in terms of size, spend and maturity participated which led us to believe that sample bias could be ignored. These businesses procured very high technology, military equipment spare parts, repair and engineering design services and each team was composed of engineers, procurement, finance and commercial staffs. The project also took a relational perspective in identifying the main types of interaction and thus included data collection by qualitative methods in order to capture the richness of perceptions needed to gain insight into the subtleties and cultural depth of the business problem. The method employed was to survey as many and as wide a cross-section of the team members in each pair of businesses as possible and to record and manipulate the results in Microsoft Excel spreadsheets. Once the team-leaders had studied the results, each was interviewed separately to determine the perceived reasons for the statistical results. Over 700 key points were selected from the semi-structured interviews and stored in a Microsoft Access database and organised for analysis by theoretical dimension, supply chain characteristics and relationship. Special attention was devoted to providing feedback to the research participants by means of individual relationship reports as well as head office and web-based summaries of the research findings. The production of independent, frank relationship information was highly valued by the organisations involved and in many cases relationship maintenance arrangements received a much-needed boost as a result. 
An innovative data analysis approach was adopted which allowed the quantitative results to reveal the broad statistical trends, the qualitative results to reveal the richness of the business interactions and, a means of relating both back to the theoretical framework. This is shown in Appendix 2 where each dimension is first defined and its mean satisfaction score from the quantitative data is given. Then, within emergent qualitative data groupings, example semi-structured interview key points are used to illustrate the strengths of respondent's feelings. The next Section provides conclusions from this data.

\section{Relationship Dynamics - Findings}

Dimension 1 - Relationship Creativity. The overall mean satisfaction score of 59\% was generally supported by the tone of the qualitative data. In summary, successful relationships occurred when innovative contracts existed which reduced costs and promoted customer focus. Moreover, organisational arrangements that promoted consistency and performance improvements were also valued. However, it appeared that both deliberate and unconscious expediency often came into play that reduced relationship effectiveness (people have only so much capacity to rationalise what is going on around them and they therefore naturally limit their performance to the adequate rather than the optimum (Simon, 1957)).

Dimension 2 - Relationship Stability. Forward-looking, holistic partnering arrangements supported by customer-focussed, supply chain-bolstering activities were detected. With a mean satisfaction rating of $51 \%$ however, there were a similar number of instances of negative approaches such as insular practices, disruptive organisational changes and shortterm strategies that promoted rather than countered the adverse effects of uncertainty and complexity (Williamson, 1975).

Dimension 3 -Communication. Although the mean satisfaction rating was only just above parity at $51 \%$, practitioners' comments were generally positive. Overall the importance of 
Supply Chain communication was understood and efforts were being made to improve but, there were very few examples where full supply chain integration could be demonstrated. Some instances of information impactedness (the imbalance caused by selective information disclosures, and distortions which are difficult or expensive to verify at the time and which undermine the durability of contract arrangements (Williamson, 1975)) were detected and linked directly to a feeling of powerlessness due to the monopolistic situation. But, the practical difficulties of providing regular, management focus on order book performance through the use of joint performance measurement and service level systems appeared to be the key issues.

Dimension 4 - Relationship Reliability. This dimension had the lowest mean satisfaction score of $49 \%$ which indicated that the practical implementation of SCM was considered to be difficult. A number of positive SCM aspects such as striving to improve quality ethos, service delivery and process improvement were observed in the data. However, environmental limitations on time, budget and investment and, product technical complexity and age had a strong bearing on the monopolistic business environment under scrutiny. It is evident that instances of opportunistic behaviour (a lack of candour or honesty and includes self-interest seeking with guile (Williamson, 1979)) were prompted as reactions to these features.

Dimension 5 - Relationship Quality. This dimension achieved the highest mean satisfaction score of $66 \%$. However, the qualitative data gave a generally more pessimistic impression although managers generally felt that they had no option but to try and make the best of their situation. There appeared to be clear evidence of working together in the best interests of relationships but, in many cases the sides felt trapped and at the mercy of the other sides' budgetary, commercial and bureaucratic vagaries. In a small numbers situation, the parties 
could resort to countering problematic behaviours, including lack of trust, by providing increasingly sophisticated controls that could, by reducing managers' freedom of action precipitate a further reduction of trust and a negative cycle of reactions (Williamson, 1979).

\section{Discussion of Results}

Contrary to expectations, a diversity of positive, business-driven behaviours as well as more adverse monopolistic dynamics were present within the UK Defence Procurement environment. The mean satisfaction scores by dimension from the quantitative data findings shown in Figure 2 usefully revealed that the essentially negative Organisations Failure Framework was not so in practice with an overall success rating of $57 \%$.

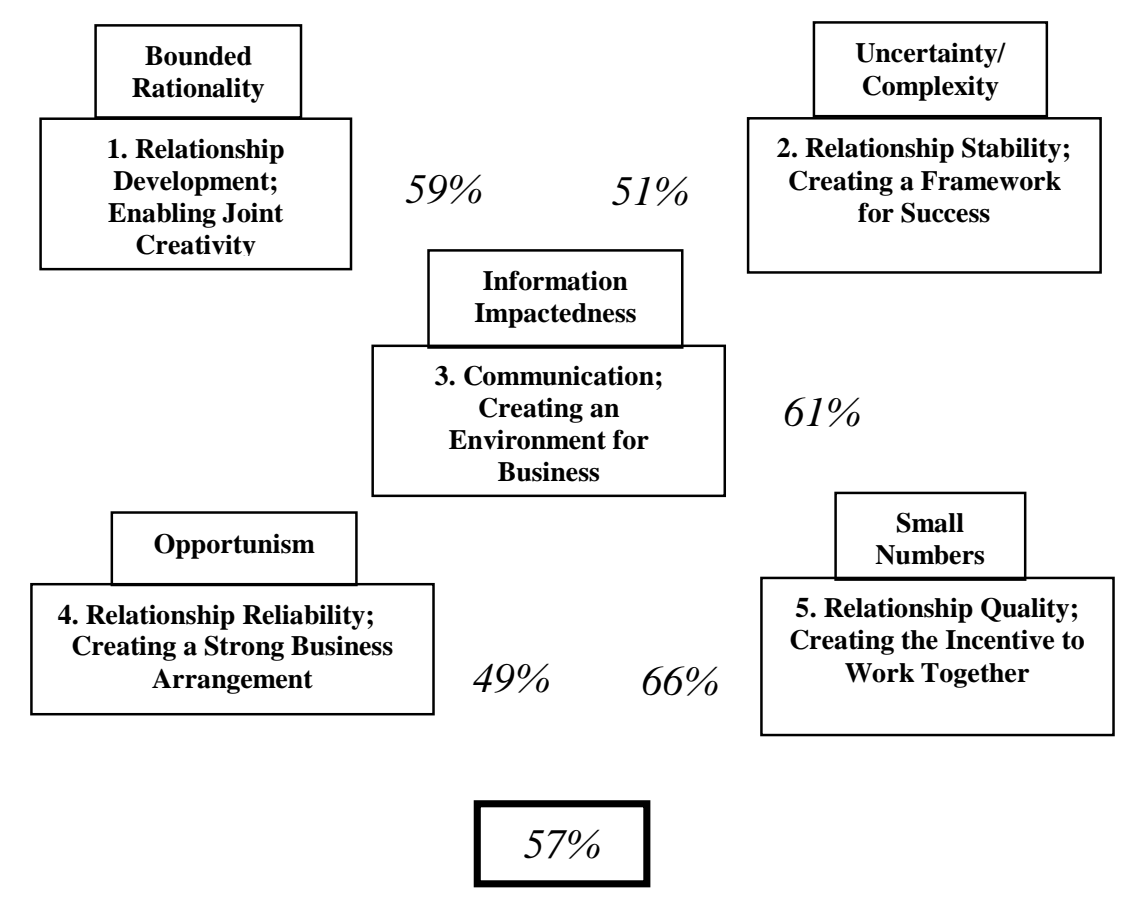

Figure 2. Overall Conceptual Framework Results by Dimension

These findings are borne out by the data described in the previous section. Difficulties in achieving effective SCM implementation could be traced to the normal, commercial difficulties surrounding order book performance, joint objectives and service level systems framework (Humphries \& Wilding, 2004, Lamming, 1993, Tompkins, 2000). Environmental 
problems such as old products, obsolescence, staff and organisational upheavals, poor endcustomer visibility and lack of investment in modern procedures and systems seemed to accentuate managers' frustrations due to lack of freedom of action and promoted the relationship negativity implied by the theoretical framework. As predicted by the model, lack of investment in specific assets such as work force stability and product/process development, the use of inadequate performance measures, opportunistically providing poor goods and services and, using proprietary information as a weapon, reduced the chances of achieving interdependence and equitable outcomes. On the other hand despite the adverse monopolistic influences, strong counterbalancing, positive business drivers were able to produce examples of relationship-building, specific investments, co-operative behaviour, open communications and a desire to reduce the burden of governance through more equitable, long-term arrangements.

Although the research was designed to take an aggregate view of the data and did not differentiate between the views of the MoD and Industry respondents, it was noticeable that qualitative opinions were reasonably balanced. However, quantitatively MoD staffs were less optimistic (59\%) than Industry (67\%). Statistical analysis indicates that this difference is not significant with a high correlation factor of 0.928 (Sapsford, 1999). From the data collected no explanation could be found for the difference in perception but further research into the phenomenon might prove interesting.

This research aimed to provide an understanding of the supply chain relationship dynamics within long-term, collaborative businesses of the type found within UK Defence Procurement and, to provide managers in this environment with some pointers on successful partnering within monopolistic businesses. The findings have exposed the reasons for tensions within the MoD/Industry relationships and described the success factors that appear 
to prevail in the face of the potential difficulties described in Figure 1. Some advice for practitioners is given later but next we describe the implications for theory.

\section{Implications for Theory}

Williamson's (1975) Organisations Failure Framework was selected as the theoretical model because it appeared to provide a means of examining the relational dynamics within a sustained monopolistic business. Because the business focus was collaborative supply chain management, the relational aspects of SCM were used as the theoretical field with which expose the interactions between the pairs of business partners using an exploratory research methodology. From the emergent groupings of qualitative data reinforced by the quantitative satisfaction ratings revealed by the questionnaires it was found that despite the forced partnership monopolistic situation, the process efficiency aims of SCM as found in 'normal' markets were present. Also, although considerable efforts were being devoted to improving SCM performance, in concert with Spekman et al's (1998) commercial sector findings, successfully implemented examples were difficult to achieve. However, negative behaviour symptomatic of the theoretical monopoly environment was also prominent. This included evidence of managers' frustration at the lack of freedom of action where relationship 'carelessness' destroyed trust (Macbeth \& Ferguson, 1994). Lambert et al's (1996) Partnering process model demonstrates the important features that impact upon partners when establishing and maintaining a partnership and describes a continuous improvement approach

with the reinforcement of success. Under monopolistic conditions the partners have no choice in the arrangement and depending on the degree of negativity affecting the business drivers for co-operation and the facilitators deployed to operationalise the relationship will, through a negative feedback loop, potentially generate a self-reinforcing, low quality relationship (Humphries \& Wilding, 2004). We conclude that these findings support 
Williamson's (1975) concepts when applied to sustained, public sector, monopolistic, business relationships and moreover, provide additional evidence that builds upon Spekman et al's (1998) work in addressing the reasons why SCM relationships are difficult to implement and sustain.

\section{Advice for Practitioners}

As mentioned in the introduction to this paper, UK Defence Procurement relationships are extremely important to both national and industrial policies such that any improvements in performance is likely to be extremely beneficial to all concerned. This research has taken an innovative approach to the analysis of this important situation and as a result has highlighted a primary lesson for managers operating within these sustained monopolies. If they are to achieve the Government's demand for improved value for money in UK Defence spending through partnering relationships with industry there is a prime need to accept that the monopoly environment will inevitably reduce relationship quality due to the limited availability of options for action. Allowing frustration and generate negative behaviours to enter a negative cycle only results in poor returns for both sides. On the contrary, it is essential to build an inventory of environmental problems that are normally considered to be 'unavoidable features of the business' and jointly seek innovative ways of dealing with them. Synchronised objectives, pursuing joint approaches to service and product delivery, lowering costs and risks and promoting measures to support the growth of trust appear to be the best ways of mitigating the negative influences of the endemic monopoly situation on supply chain relationships. Finally, the research has proved the benefit of an independent, $3^{\text {rd }}$ party review of supply chain relationship development and suggests that periodic repeats would allow areas for joint management attention to be targeted. 


\section{Further Research Opportunities}

This research has, for the first time achieved a high level, cross-relationship (UK $\mathrm{MoD} /$ Industry) perspective of a significant sample of sustained monopoly businesses and this supply chain activity continues to struggle to achieve its objectives in a market that becomes more and more restricted. Further research is necessary to build on our initial, exploratory efforts in order to probe more deeply into an extremely interesting area. It would be useful to repeat the approach in order to obtain a longitudinal view of the relationships to determine what change is occurring over time and why and provide more detailed understanding of the organisational and personal interactions. Such an approach could be aimed at providing more specific improvement programmes and be targeted both tactically and strategically. Traditionally economics has taken a rather limited view of monopoly in areas such as the governance arrangements for public utilities or the application of anti-trust legislation (Rindfleisch \& Heide, 1997). This research echoes Parker and Hartley's conclusions that economists might also find the examination of 'public interest' monopolies interesting. Lastly, there are possible similarities between the UK Defence monopolistic supply chain relationships and long term collaborations in the private sector. Not only would the repeat of our research approach in the commercial arena, both nationally and internationally, triangulate our findings but it might also offer researchers another way of cross-tabulating their own projects. It should be emphasised that none of these opportunities for research should be viewed in isolation; many of them overlap and converge to offer the chance to carry out integrated research programmes.

\section{Conclusion}

The literature suggests that the little known about the relationship dynamics within monopolies presupposes negative outcomes. However, this research has shown that this is 
not the case, and that within the relationships examined a spectrum of positive and negative results were found. This is especially interesting because it demonstrates that Supply Chain Management factors, as described in 'normal' markets literature, are equally important success factors in monopolistic business. The research findings thus shed new light in an area that has received little attention by management researchers (Palmer, 2001, Parker \& Hartley, 1997). They also provide valuable practical advice to managers and offer academics a potentially interesting agenda for future research to gain extended perspectives of longterm, collaborative, supply chain relationships. 


\section{Appendix 1 - Questionnaire Dimensions and Questions}

1. Bounded Rationality - Creativity: promoting quality, innovation and long-term approach by encouraging high performance.

a. The relationship encourages the achievement of high performance by both parties ie. reliable equipment, on-time delivery, good forecasts.

b. The relationship encourages us to be innovative in the way we do business.

c. Performance measurement is used to raise standards.

d. Disputes \& problems are resolved: 'quickly'.

e. Disputes \& problems are resolved: 'fairly'.

f. The other party is reliable and consistent in dealing with us.

g. The other party is dedicated to making our business a success.

h. When an unexpected problem arises, both parties would rather work out a solution than hold each other to the original contract terms.

2. Uncertainty/Complexity - Stability: synchronisation of objectives and confidence building.

a. The other party displays a sound, strategic understanding of our business.

b. The objectives of both parties are clearly stated.

c. The objectives of both parties are fully compatible.

d. Both parties co-operate wholeheartedly.

e. The relationship provides a dynamic business environment within which both parties can seek increasing rewards.

f. I have complete confidence in the intentions of the other party.

3. Information Impactedness - Communication: shared data environment, openness, common performance measures, frequent interaction.

a. Where the other party has proprietary information that could improve the performance of the joint business, it is freely available.

b. We would welcome a shared data environment where planning, technical and pricing information are made freely available.

c. We understand the information requirements of all participants in the support chain from sub-contractors to end-user.

d. Exchange of information in this relationship takes place frequently and informally - not just according to specified agreement.

e. Objective performance measurement is an important part of this relationship.

f. We are aware of the performance requirements for all participants in the support chain from sub-contractors to end-user.

g. We provide the other party with regular information including long-range forecasts to enable him to do his business better.

4 Opportunism - Reliability: concentrating on service and product delivery, lowering joint costs and risks, building up trust.

a. The quality of the contract outputs ie. spares/repairs/services, is entirely satisfactory.

b. The quality of service delivery ie. delivery times, billing, payment, is entirely satisfactory.

c. The relationship is characterised by a continually improving quality ethos. 
d. Problems are solved in a joint, open, constructive manner.

e. Such is the goodwill in the relationship, the other party would willingly put himself out to adapt to our changing requirements.

f. We trust the other party to act in our best interests.

g. The responsibility for making sure the relationship works is shared jointly.

h. The other party provides us with useful cost reduction and quality improvement ideas.

i. The other party is always totally open and honest with us.

j. The other party always does what he says he will do.

5. Small Numbers - Quality: creating a win-win relationship in which each side is delighted to be a part.

a. The gains from this relationship are equally shared between both parties.

b. We do not feel imprisoned within the current relationship.

c. We are willing to invest more ie. money, time, information, effort, in the current relationship.

d. We are happy that our future is bound to the success of our relationship partner.

e. We feel totally committed to this relationship.

f. The other party is genuinely concerned that our business succeeds.

g. Both sides are working to improve this relationship. 


\section{Appendix 2 - Qualitative Data Analysis Examples}

\begin{tabular}{|c|c|c|c|}
\hline Dimension & Definition & Emergent Grouping & Example Practitioner Comments \\
\hline \multirow[t]{10}{*}{$\begin{array}{l}1- \\
\text { Relationship } \\
\text { Creativity } \\
(59 \%)\end{array}$} & \multirow{10}{*}{$\begin{array}{l}\text { Promoting quality, } \\
\text { innovation and a } \\
\text { long-term approach } \\
\text { by encouraging high } \\
\text { performance }\end{array}$} & \multirow[t]{4}{*}{$\begin{array}{l}\text { Flexible commercial } \\
\text { approach based upon } \\
\text { framework contracting } \\
\text { Planning \& control }\end{array}$} & $\begin{array}{l}\text { 'Now we have a partnering arrangement } \\
\text { around a good framework contract we just } \\
\text { concentrate of the customer - we no longer } \\
\text { refer to the small print' }\end{array}$ \\
\hline & & & $\begin{array}{l}\text { 'Enabling contracts reduce admin costs by } \\
\text { freeing us from frequent competitions as } \\
\text { long as the company continues to } \\
\text { demonstrate it has given us best value for } \\
\text { money' }\end{array}$ \\
\hline & & & $\begin{array}{l}\text { 'We used to keep a pool of items to feed } \\
\text { into repair. With our new partnering } \\
\text { arrangement we track individual items and } \\
\text { have significantly cut down on their } \\
\text { number' }\end{array}$ \\
\hline & & & $\begin{array}{l}\text { 'The benefits of the partnering arrangement } \\
\text { are we are 'future-proofed', uncertainty is } \\
\text { removed, we can plan and most } \\
\text { importantly, we can really focus on the } \\
\text { customer' }\end{array}$ \\
\hline & & \multirow[t]{2}{*}{ Service delivery } & $\begin{array}{l}\text { 'This is real support chain management; the } \\
\text { mechanism is invisible to the end customer' }\end{array}$ \\
\hline & & & $\begin{array}{l}\text { 'Industry is still rooted in the past; it is not } \\
\text { yet prepared for long-term service } \\
\text { provision' }\end{array}$ \\
\hline & & \multirow[t]{4}{*}{$\begin{array}{l}\text { Joint operations and } \\
\text { organisational } \\
\text { arrangements }\end{array}$} & $\begin{array}{l}\text { 'My team is only } 60 \text { strong and small is } \\
\text { beautiful. We seem to be able to do more } \\
\text { with less. We concentrate on essentials; the } \\
\text { nice to do only encourage growth in } \\
\text { overheads' }\end{array}$ \\
\hline & & & $\begin{array}{l}\text { 'The company is dealing with an old } \\
\text { product, the spares are in short-supply, } \\
\text { there are obsolescence problems and on top } \\
\text { of that, its organisation is poorly focussed' }\end{array}$ \\
\hline & & & $\begin{array}{l}\text { 'We now sit down with the customer to } \\
\text { write his Post Design Services } \\
\text { requirements. This saves months of } \\
\text { bureaucracy' }\end{array}$ \\
\hline & & & $\begin{array}{l}\text { 'The relationship between our people is } \\
\text { excellent but frequent staff changes in their } \\
\text { team disrupt our working arrangements and } \\
\text { incur costs' }\end{array}$ \\
\hline \multirow[t]{5}{*}{$\begin{array}{l}2- \\
\text { Relationship } \\
\text { Stability } \\
(51 \%)\end{array}$} & \multirow[t]{5}{*}{$\begin{array}{l}\text { The synchronisation } \\
\text { of objectives and } \\
\text { confidence building }\end{array}$} & \multirow[t]{2}{*}{ Customer focus } & $\begin{array}{l}\text { 'We organised a training day on the } \\
\text { Ministry of Defence's site to educate their } \\
\text { staff about the company and its products. } \\
\text { Knowledge about each other's business is } \\
\text { important to our professional relationship' }\end{array}$ \\
\hline & & & $\begin{array}{l}\text { 'They don't seem to understand we have } \\
\text { lead times; they often want it 'tomorrow' }\end{array}$ \\
\hline & & \multirow[t]{2}{*}{$\begin{array}{l}\text { Commercial } \\
\text { understanding }\end{array}$} & $\begin{array}{l}\text { 'We aim for a } 10,12,15 \text { or even } 30 \text { year } \\
\text { contract. This fosters a long-term ethos, } \\
\text { cuts the costs of frequent renegotiations and } \\
\text { allows the Firm to plan and resource' }\end{array}$ \\
\hline & & & $\begin{array}{l}\text { 'We gave them a proper solution. They } \\
\text { said it was too expensive. We cut back and } \\
\text { now we are all suffering' }\end{array}$ \\
\hline & & Co-operation & 'They are always thinking ahead; wanting \\
\hline
\end{tabular}




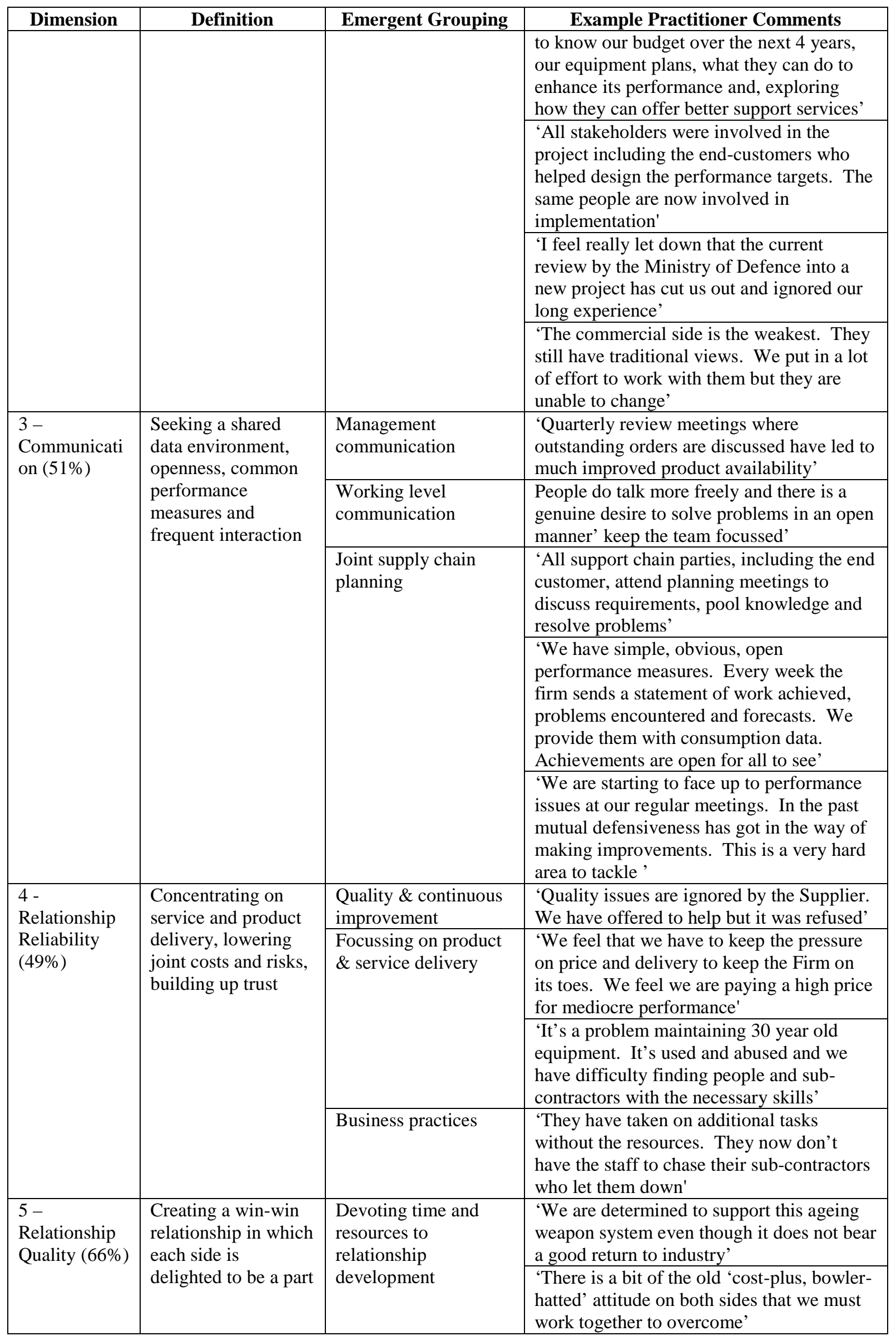




\begin{tabular}{|c|c|c|c|}
\hline Dimension & Definition & Emergent Grouping & Example Practitioner Comments \\
\hline & & \multirow[t]{2}{*}{$\begin{array}{l}\text { Understanding the } \\
\text { difficulties of doing } \\
\text { business in Defence } \\
\text { Procurement and the } \\
\text { level of equity in the } \\
\text { partnership }\end{array}$} & $\begin{array}{l}\text { 'Our fear is the feast and famine situation of } \\
\text { Defence spending. There are times when } \\
\text { we must stop work, lay off experienced } \\
\text { staff and then race to get back going again. } \\
\text { I worry that we cannot respond fast enough } \\
\text { and that this adversely affects customer- } \\
\text { satisfaction' }\end{array}$ \\
\hline & & & $\begin{array}{l}\text { 'Their worry is that because we are their } \\
\text { single source and have changed hands a } \\
\text { couple of times in the last } 10 \text { years, we } \\
\text { might go out of business and leave them } \\
\text { high and dry' }\end{array}$ \\
\hline
\end{tabular}




\section{References}

Anscombe, J \& Kearney, A T (1994) Partnership or Power Play? Logistics Focus 2(6).

Bechtel, C \& Jayaram, J. (1997) Supply Chain Management: A Strategic Perspective. The International Journal of Logistics Management 8(1), pp. 15-34.

Boddy, D, Macbeth, D, \& Wagner, B. (2000) Implementing Cooperative Strategy: A Model from the Private Sector. In: David O Faulkner and Mark de Rond (Eds) . Cooperative Strategy: Economic, Business and Organisational Issues, Oxford University Press, New York, p. 195.

Braithwaite, A. (1998) The Nine Maxims of Supply Chain Management. Proceedings of the Logistics Research Network Conference 10/11 Sep 98 Cranfield.

Brooks, AD \& Pawar, K. (2000) Dynamics of User/Contractor Interface in The Public Sector Disentangled. Proceedings of the $9^{\text {th }}$ International Annual IPSERA Conference \& Worldwide Symposium on Purchasing \& Supply Chain Management, 24-27 May pp.99-109, University of Western Ontario.

Christopher, M. (1997) Marketing Logistics. Butterworth-Heinemann, Oxford.

Cooper, MC \& Ellram, LM. (1993) Characteristics of Supply Chain Management \& the Implications for Purchasing \& Logistics Strategy. The International Journal of Logistics Management 4(2), pp.13-24.

Cooper, MC, Lambert, DM, \& Pagh, JD. (1997) Supply Chain Management: More than a New Name for Logistics. The International Journal of Logistics Management 8(1), pp.1-14.

Cox, A. (2000) The Power Perspective in Procurement and Supply Management. Journal of Supply Chain Management (Spring), pp. 4-7.

DASA. (2002) UK Defence Statistics 2002. MoD/HMSO, Norwich.

Ellram, LM \& Edis, Owen RV. (1996) A Case Study of Successful Partnering Implementation. International Journal of Purchasing \& Materials Management (Sep), pp. 20-38.

Harland, CM, Gibbs, J \& Sutton, R (2000) Supply Strategy for the Public Sector: Framing the Issues, The $9^{\text {th }}$ International IPSERA Conference Proceedings 24/27 May, pp 342351.

Hulme, MR. (1997) Procurement Reform \& MIS Project Success. International Journal of Purchasing \& Materials Management 33(Winter), pp. 2-15.

Humphries, AS \& Wilding, R. (2000) Partnering in UK Defence Procurement: Myth or Reality? Proceedings of the Logistics Research Network 5th Annual Conference 7th \& 8th September, pp. 281-289. Cardiff University.

Humphries, AS \& Wilding, R. (2001) Partnerships in UK Defense Procurement. The International Journal of Logistics Management 12(1), pp 83-96. 
Humphries, AS and Wilding, R. (2004) Sustained Monopolistic Business relationships: A UK Defence Procurement Case. European Journal of Marketing 37(forthcoming).

Lambert, DM, Emmelhainz, MA, \& Gardner, JT. (1996) Developing and Implementing Supply Chain Partnerships. The International Journal of Logistics Management 7(2), pp. 1-17.

Lamming, RC. (1993) Beyond Partnership: Strategies for Innovation \& Lean Supply. Prentice Hall, London.

Macbeth, DK \& Ferguson, N. (1994) Partnership Sourcing: An Integrated Supply Chain Management Approach. Pitman, London.

Matthyssens, P \& Van den Bulte, C. (1994) Getting Closer and Nicer: Partnerships in the Supply Chain. Long Range Planning 27(1), pp. 72-83.

Palmer, A. (2001) Co-operation and Collusion: Making the Distinction in Marketing Relationships. Journal of Marketing Management 17, pp 761-784.

Parker, D \& Hartley, K. (1997) The Economics of Partnership Sourcing Versus Adversarial Competition: A Critique. The European Journal of Purchasing \& Supply Management 3(2), pp. 115-125.

Peck, H \& Jüttner, U. (2000) Strategy and Relationships: Defining the Interface in Supply Chain Contexts. The International Journal of Logistics Management 11(2), pp. 33-44.

Porter, ME. (1980) Competitive Strategy. The Free Press, New York.

Rindfleisch, A \& Heide, JB. (1997) Transaction Cost Analysis: Past, Present, and Future Applications. Journal of Marketing 61(Oct), pp. 30-54.

Sapsford, R. (1999) Survey Research. SAGE, London.

Simon, HA. (1957) A behavioral model of rational choice. Models of Man, John Wiley, New York. In: Hatch, Mary Jo. Organisation Theory, p. 274 Oxford, Oxford University Press, 1997.

Spekman, RE, Kamauff, JW Jr, \& Myhr, N. (1998) An Empirical Investigation into Supply Chain Management: A Perspective on Partnerships. Supply Chain Management 3(2), pp. 53-67.

Stevens, GC. (1989) Integrating the Supply Chain. International Journal of Physical Distribution \& Logistics Management 19(8), pp. 3-8.

Tompkins, JA. (2000) No Boundaries: Moving Beyond Supply Chain Management. p 53. Tompkins Press, Raleigh, NC.

Williamson, OE. (1975) Markets \& Hierarchies: Analysis \& Anti-trust Implications. pp. 3940. The Free Press, New York.

Williamson, OE. (1979) Transaction-cost Economics: The Governance of Contractual Relations. Journal of Law \& Economics 22, pp. 233-261. 
Zheng, J, Harland, CM, Lamming, RC, Johnsen, T \& Wynstra, F. (2000) Networking activities in supply networks. Journal of Strategic Marketing. 8, pp. 161-181. 